\title{
Plants and cardiac glycosides
}

\author{
A HOLLMAN \\ From the Cardiac Department, University College Hospital, London
}

It is often asked why plants contain such remarkable compounds, sometimes beyond the practical reach of the synthetic chemist. What use are these compounds to the plant itself? Defence against predators is one answer although it has to be said that many of today's predators did not exist when the flowering plants, the angiosperms, evolved 80-100 million years ago. It has been shown for example that the methylxanthines in tea and coffee have static and cidal activity against insect pests. ${ }^{1}$

Glycosides are usually compounds of plant origin. They are made up of one or more sugars combined with an alcohol, a phenol, or a complex molecule such as a steroid nucleus. The non-sugar moiety or aglycone is also called a genin. Because they do not contain nitrogen it is wrong to call them alkaloids. In addition to the cardiac glycosides with their cyclopentanoperhydrophenanthrene nucleus in the genin moiety there are other glycosidal plant substances such as the anthraquinone derivatives senna, rhubarb, aloe, and cascara; saponins; cyanogenetic glycosides such as amygdalin from bitter almond; terpene and sterol glycosides; glycosidal dyes and pigments; and finally gums and tannins. The venom glands of the skin of the toad (Bufo) contain digitalis like compounds and this animal gives its name to that group of the glycosides which have a steroid skeleton of 24 carbon atoms $\left(C_{24}\right)$, the bufadienolides. A few plant glycosides also belong to this group, notably those from squill, but all others have a $\mathrm{C}_{23}$ skeleton and belong to the cardenolides group.

The genus Digitalis is named after the shape of the flowers (digitus, a finger). Although ingenious alternatives have been proposed to explain the common name, foxglove, there is no doubt that this title does mean the glove of a fox. The genus comprises biennial or perennial herbs, or rarely small shrubs, with leaves which are simple, arranged alternately, and sometimes with the lowest leaves forming a rosette. They are natives of Europe, North Africa, and West Asia but not of China. The formerly named

Requests for reprints to Dr A Hollman, Cardiac Department, University College Hospital, London WC1E 6AU.
$D$ chinensis has been reclassified as Adenosma grandiflorum. The showy flowers are purple, yellowish brown, or white, carried in terminal racemes. The calyx has five equal lobes and there are four stamens. Other characteristics are variable and on the basis of these differences the genus is divided into twelve species and seven subspecies. The full taxonomy $y^{2}$ of Digitalis is as follows: class, Angiospermae; subclass, Dicotyledon; superorder, Asteridae; order, Scrophulariales; family, Scrophulariaceae; subfamily, Rhinanthoideae; tribe, Digitalideae; genus, Digitalis. $D$ purpurea is the only species native to Britain. It is also found in Western Europe and is a complex polytypic species with at least three subspecies. The flowers are purple, pale pink, or white and being usually calcifuge it is rare in calcareous districts such as Cambridgeshire and the Jura. The species $D$ lanata which comes from Hungary, Romania, and the Balkan peninsula has white or yellowish white flowers with brown or violet veins and was introduced to Britain in 1789. This species is named after its characteristically downy flowers. Other species ${ }^{3}$ include $D$ obscura, $D$ thapsis, $D$ dubia and $D$ parviflora from Spain; $D$ viridiflora and $D$ laevigata from the Balkan peninsula; $D$ lutea, $D$ grandiflora, and $D$ ferruginea from western, eastern, and southern Europe respectively; $D$ leucophaea from northern Greece; $D$ orientalis from the Levant; $D$ sibirica from Siberia.

The native glycoside is susceptible to hydrolysis by enzymes during the extraction process. The acetyl group and glucose are split off, but fortunately the partly hydrolysed glycosides such as digoxin and digitoxin are as biologically active as the parent compound. Were this not so the action of digitalis might never have been established since the native compounds were first isolated by A Stoll as late as 1935 . The native compounds in D lanata are lanatosides $\mathrm{A}$, $B$, and $C$ which yield digitoxin, gitoxin, and digoxin (Table 1). D purpurea has purpurea glycosides $A$ and B but no glycoside corresponding to lanatoside $C$. Digitoxin comes from $D$ ferruginea, $D$ grandiflora, $D$ lanata, $D$ lutea, and four varieties of $D$ purpurea. Digoxin comes from $D$ grandiflora, $D$ lanat $a$, and $D$ orientalis. 
It was the poisonous nature of other plants which contain cardiac glycosides which first drew attention to them not the typical chemical structure of the glycosides that they contain. In 1898 Lauder Brunton wrote, "various drugs stimulate the vagus roots in the medulla oblongata or the terminal endings of the heart itself ... many of the arrow poisons and ordeal poisons act on the heart in this way, among them are strophanthus, erythrophloeum, tanghinia, manganja, carravol, vao, oleander, squill, hellebore ...".4 Many plants contain cardiac glycosides and some species contain up to six. One glycoside may be present in several species; strophanthidin for example is found in 10 genera from 7 families.

There are 36 cardiac genins of plant origin and they are divided into six groups according to their accompanying sugars. There is no obvious pattern for the occurence of glycosides in different plants.

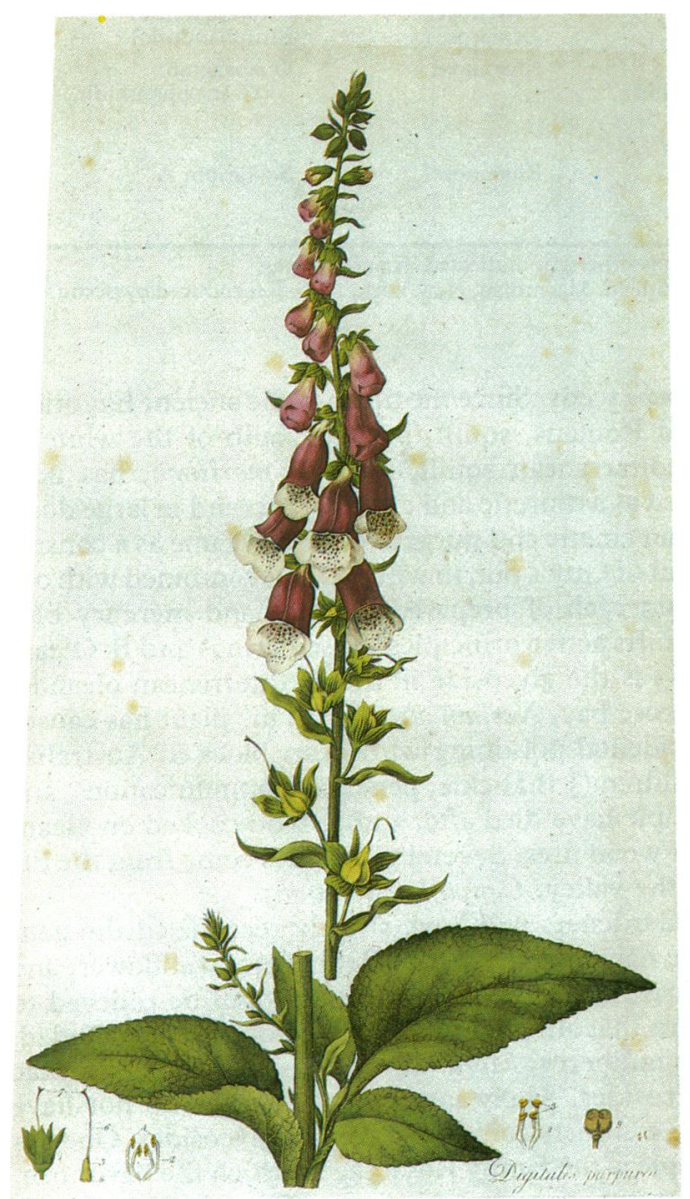

Digitalis purpurea (L) (Source: Curtis W. Flora Londinensis, Vol 1. London, 1777.)
They occur both in monocotyledons (for example Liliaceae) and in dicotyledons, and their geographical distribution is irregular, as is the distribution of other important plant medicines. For example, podophyllotoxin from which the anticancer drug etoposide is derived is found in two Podophyllum species, one from the Himalayas and the other from North America. Because the taxonomy of plants according to their chemical composition is not fully developed, the list of the families and their genera which contain cardiac glycosides given in Table 2 is based on the Linnaean classification. ${ }^{5}$

A few glycosides and plants may be picked out for special mention. Ouabain, which is ineffective when given by mouth, comes from the wood of Acocanthera schimperi, the Ouabaio tree, and also from the seeds of Strophanthus gratus. It is more familiar to pharmacologists than to clinicians, as is strophanthin K a glycoside mixture from Strophanthus

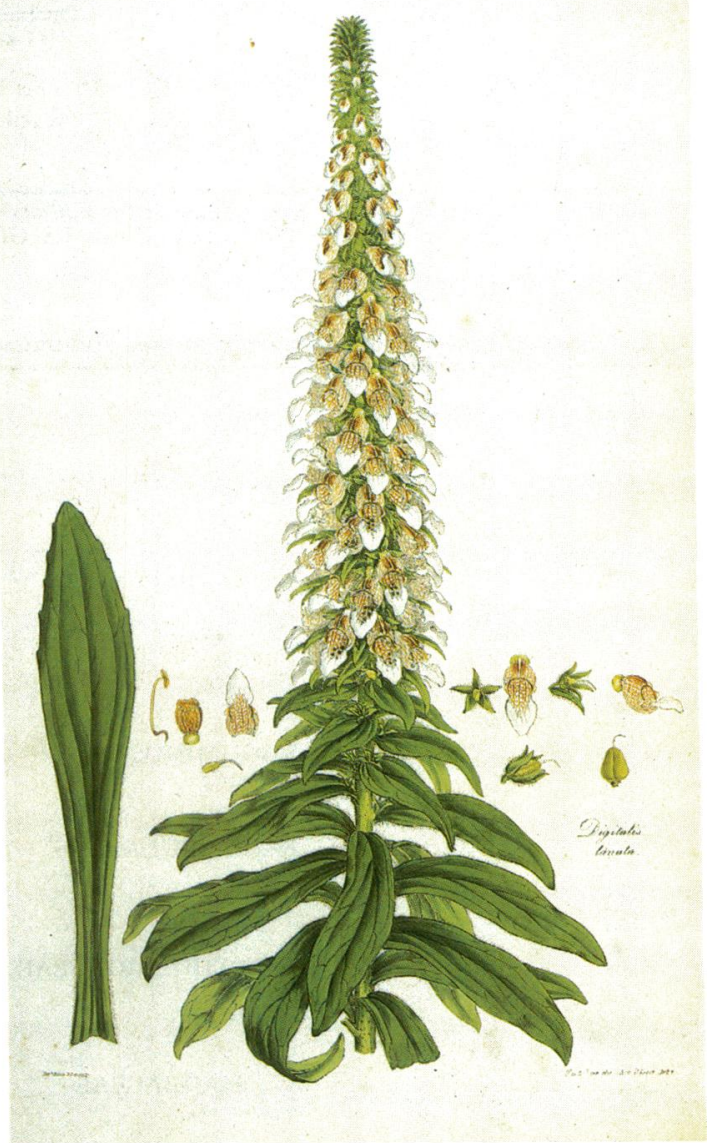

Digitalis lanata (Ehr) (Source: Lindley J. Digitalium monographia. London, 1821.) 
Table 1 Botanical sources and major chemical components of cardiac glycosides of clinical importance

\begin{tabular}{|c|c|c|c|c|c|}
\hline $\begin{array}{l}\text { Plant } \\
\text { source }\end{array}$ & $\begin{array}{l}\text { Precursor } \\
\text { glycoside }\end{array}$ & $\begin{array}{l}\text { Split off by } \\
\text { enzymatic } \\
\text { and mild } \\
\text { alkaline } \\
\text { hydrolysis }\end{array}$ & Glycoside & $\begin{array}{l}\text { Split off by } \\
\text { acid hydrolysis }\end{array}$ & Aglycone or genin \\
\hline & & & Digitalis & & \\
\hline \multirow{3}{*}{$\begin{array}{l}D \text { purpurea } \\
\text { (leaf) }\end{array}$} & \multirow{3}{*}{$\begin{array}{c}\text { Purpurea-glycoside A } \\
\text { (deacetyldigilanid A) } \\
\text { Purpurea-glycoside B } \\
\text { (deacetyldigilanid B) } \\
\text { - }\end{array}$} & Glucose & Digitoxin & Digitoxose (3) & Digitoxigenin \\
\hline & & Glucose & Gitoxin & Digitoxose (3) & Gitoxigenin \\
\hline & & - & Gitalin & Digitoxose (2) & $\begin{array}{l}\text { Gitaligenin } \\
\text { (gitoxigenin hydrate) }\end{array}$ \\
\hline \multirow[t]{4}{*}{$\begin{array}{l}D \text { lanata } \\
\text { (leaf) }\end{array}$} & \multirow{4}{*}{$\begin{array}{l}\text { Lanatoside A } \\
\text { (digilanid A) } \\
\text { Lanatoside B } \\
\text { (digilanid B) } \\
\text { Lanatoside C } \\
\text { (digilanid C; } \\
\text { cedilanid) }\end{array}$} & \multirow{3}{*}{$\begin{array}{l}\text { Glucose }+ \\
\text { acetic acid } \\
\text { Glucose }+ \\
\text { acetic acid } \\
\text { Glucose }+ \\
\text { acetic acid }\end{array}$} & Digitoxin & Digitoxose (3) & Digitoxigenin \\
\hline & & & Gitoxin & Digitoxose (3) & Gitoxigenin \\
\hline & & & Digoxin & Digitoxose (3) & Digoxigenin \\
\hline & & & Strophanthus & & \\
\hline \multirow[t]{2}{*}{$\begin{array}{r}S \text { kombé } \\
\text { (seed) }\end{array}$} & K-strophanthoside & Glucose & $\begin{array}{c}\text { K-strophanthin- } \beta \\
\text { (strophanthin) }\end{array}$ & $\begin{array}{l}\text { Glucose }+ \\
\text { cymarose }\end{array}$ & Strophanthidin \\
\hline & $\begin{array}{l}\text { K-strophanthoside } \\
\text { K-strophanthin- } \beta\end{array}$ & $\begin{array}{l}\text { Glucose (2) } \\
\text { Glucose }\end{array}$ & $\begin{array}{l}\text { Cymarin } \\
\text { Cymarin } \\
\text { Cymarol }\end{array}$ & $\begin{array}{l}\text { Cymarose } \\
\text { Cymarose } \\
\text { Cymarose }\end{array}$ & $\begin{array}{l}\text { Strophanthidin } \\
\text { Strophanthidin } \\
\text { Strophanthidol }\end{array}$ \\
\hline $\begin{array}{c}S \text { gratus } \\
(\text { seed })\end{array}$ & - & - & $\begin{array}{l}\text { Ouabain } \\
\text { (G-strophanthin) }\end{array}$ & Rhamnose & $\begin{array}{l}\text { Ouabagenin } \\
\text { (G-strophanthidin) }\end{array}$ \\
\hline $\begin{array}{l}\text { Urginea } \\
\quad \text { maritima or } \\
\text { indica (bulb) }\end{array}$ & Scillaren A & Glucose & $\begin{array}{c}\text { Scilla (squill) } \\
\text { Proscillaridin A }\end{array}$ & Rhamnose & Scillaridin A \\
\hline
\end{tabular}

* One mole of sugar or acetic acid is split off, unless the number of moles is otherwise indicated in parentheses.

(From The Pharmacological Basis of Therapeutics. Goodman LS, Gilman A. 5th ed. Macmillan, New York, 1975. Reproduced by permission of the authors and publisher.)

Table 2 Families and genera containing cardiac glycosides

\begin{tabular}{|c|c|}
\hline $\begin{array}{l}\text { APOCYANACEAE } \\
\text { Acokanthera } \\
\text { Adenium } \\
\text { Apocyanum } \\
\text { Carissa } \\
\text { Cerbera } \\
\text { Nerium } \\
\text { Strophanthus } \\
\text { Tanghinia } \\
\text { Thevetia }\end{array}$ & $\begin{array}{l}\text { LILIACEAE } \\
\text { Bowiea } \\
\text { Convallaria } \\
\text { Ornithogalum } \\
\text { Rohdea } \\
\text { Urginea } \\
\\
\text { MORACEAE } \\
\text { Antiaris } \\
\text { Antiaropsis } \\
\text { Castilla } \\
\text { Ogcodeia }\end{array}$ \\
\hline $\begin{array}{l}\text { ASCLEPIADACEAE } \\
\text { Asclepias } \\
\text { Calotropis } \\
\text { Cryptostegia } \\
\text { Gomphocarpus } \\
\text { Menabea } \\
\text { Pachycarpus } \\
\text { Periploca } \\
\text { Xysmalobium }\end{array}$ & $\begin{array}{l}\text { LEGUMINOSAE } \\
\text { Coronilla } \\
\text { RANUNCULACEAE } \\
\text { Adonis } \\
\text { Helleborus }\end{array}$ \\
\hline \multirow{2}{*}{$\begin{array}{l}\text { CELASTRACEAE } \\
\text { Euonymus }\end{array}$} & $\begin{array}{l}\text { SCROPHULARIACEAE } \\
\text { Digitalis } \\
\text { Isoplexis }\end{array}$ \\
\hline & $\begin{array}{l}\text { STERCULIACEAE } \\
\text { Mansonia }\end{array}$ \\
\hline $\begin{array}{l}\text { CRUCIFERAE } \\
\text { Cheiranthus } \\
\text { Erysimum }\end{array}$ & $\begin{array}{l}\text { TILIACEAE } \\
\text { Corchorus }\end{array}$ \\
\hline
\end{tabular}

kombé seeds. Since the times of the ancient Egyptians and Romans, squill from the bulb of the white or mediterranean squill, Urginea maritima, has been used as a diuretic and expectorant (and in large doses as an emetic and purgative). It had fame as a constituent of Guy's pill, in which it was combined with one grain each of prepared digitalis and mercury blue pill. Its active principles are scillarin A and B. Oleandrin is the glycoside in the mediterranean oleander or rose bay, Nerium oleander. This plant has caused accidental poisoning with heart block in Australian children (J B Hickie, personal communication), and people have died after eating food cooked on oleander wood fires. Several glycosides come from the lily of the valley, Convallaria majalis.

Gardeners will have already recognised the generic names of the star of Bethlehem, wallflower, and Christmas rose, while gourmets will be relieved to learn that although the family Moraceae is included, the mulberry, Morus nigra, does not contain cardiac glycosides. Many large plant families do not have any members containing cardiac glycosides. One example is the family Rosaceae to which the hawthorn, Crataegus monogyna, belongs. This plant, however, contains a flavinoid glycoside which has a weak digitalis like action. 


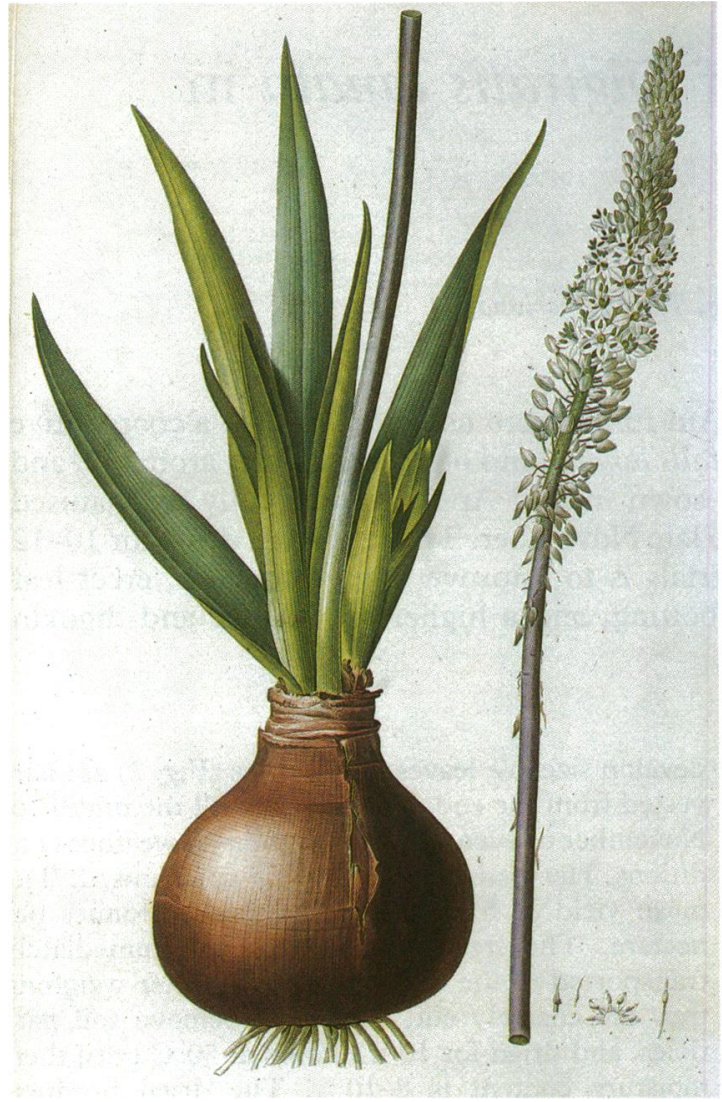

Urginea maritima (Baker) (Source: Redouté P J. Les Liliacées, Vol 2. Paris, 1805.)

Anticipating by 100 years Pasteur's dictum, "dans les champs de l'observation, le hasard ne favorise que les esprits préparés ...", it was certainly chance acting on Withering's prepared mind that gave Digitalis purpurea its scientific start in therapeutics, but many other species contain cardioactive principles and it is to be hoped that more will be discovered among the world's 250000 species, unless the accelerating pace of tropical deforestation eliminates a species before we have studied it.

I thank Mrs Gina Douglas, Librarian to the Linnean Society of London, for her help.

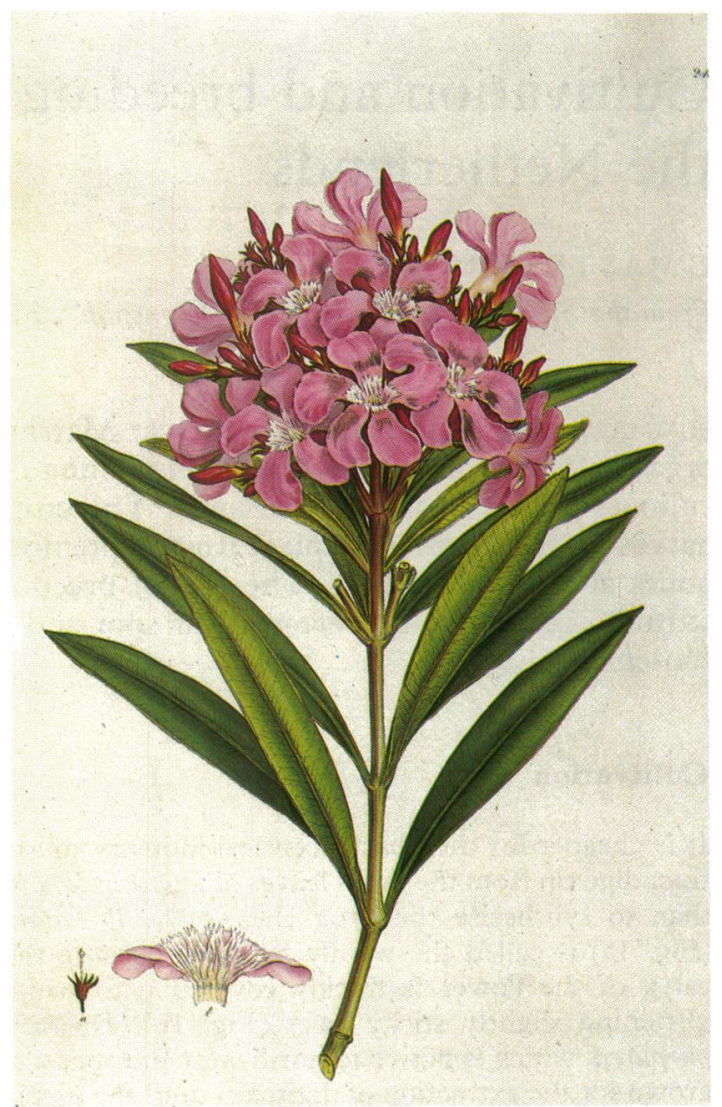

Nerium oleander (L) (Source: Sibthorp J. Flora Graeca, Vol 3. London, 1819.)

\section{References}

1 Nathanson JA. Caffeine and related methylxanthines: possible naturally occurring pesticides. Science 1984; 226: 184-7.

2 Heywood VH, ed. Flowering plants of the world. Oxford: Oxford University Press, 1978.

3 Tutin TG, ed. Flora Europea. Vol 3. Diapensiaceae to myoporaceae. Cambridge: Cambridge University Press, 1972.

4 Brunton TL. The use of remedies in diseases of the heart and blood vessels. $\mathcal{F} A M A 1898 ; 31$ : 815-7.

5 Hoch JH. A survey of cardiac glycosides and genins. Charleston: University of South Carolina Press, 1961. 